Article

\title{
Effect of Fiber and Cement Additives on the Small-Strain Stiffness Behavior of Toyoura Sand
}

\author{
Muhammad Safdar ${ }^{1, *(\mathbb{C}}$, Tim Newson ${ }^{2}\left(\mathbb{D}\right.$, Colin Schmidt $^{3}$, Kenichi Sato ${ }^{4}$, Takuro Fujikawa ${ }^{4}(\mathbb{D}$ \\ and Faheem Shah ${ }^{1}$ \\ 1 Earthquake Engineering Center, University of Engineering and Technology Peshawar, \\ Peshawar 25000, Pakistan; fshah_vfciv@uetpeshawar.edu.pk \\ 2 Department of Civil and Environmental Engineering, Western University, London, ON N6A 3K7, Canada; \\ tnewson@eng.uwo.ca \\ 3 Thurber Engineering Ltd. 180, 7330 Fisher Street SE, Calgary, AB T2H 2H8, Canada; \\ schmidt.colin5@gmail.com \\ 4 Department of Civil Engineering, Fukuoka University, 8-19-1 Nanakuma, Jonan, Fukuoka 814-0180, Japan; \\ sato@fukuoka-u.ac.jp (K.S.); takuro-f@fukuoka-u.ac.jp (T.F.) \\ * Correspondence: drsafdar@uetpeshawar.edu.pk
}

Received: 23 November 2020; Accepted: 10 December 2020; Published: 15 December 2020

\begin{abstract}
The disposal of 2011 Japan earthquake waste has become an important issue in Japan and it is not realistic or economical to send all of these wastes to landfill sites, due to limited space, high costs, and related environmental issues. In sustainable geotechnical applications, mixing of the separated soils from disaster wastes with additives (e.g., cement and fiber) is required to improve their strength and stiffness characteristics. In this study, monotonic triaxial drained compression tests are performed on medium dense specimens of Toyoura sand-cement-fiber mixtures with different percentages of fiber and cement (e.g., 0-3\%) additives. The experimental results indicate that behavior of the mixtures is significantly affected by the concentration of fiber and cement additives. Based on a comprehensive set of test results, modifications to the series of equations were developed that can be used to evaluate the shear modulus and mobilized stress curves at small-strain levels. The experimental results and model comparison show that the elastic threshold strain $\left(\gamma_{e}\right)$, reference strain $\left(\gamma_{r}\right)$, increases with fiber and cement additives. In addition, the range of curvature parameter, from 0.88 to 1.0, provides a good comparison with the results of small-strain measurements. Overall, the comparison of the results and model shows that the small-strain measurements obtained using local strain transducers fall within the range of model upper and lower bound curves. The results of the unreinforced, fiber, and cemented sand shows a close agreement with the model mean curve, but fiber-reinforced cemented sand shows a good comparison with model upper bound.
\end{abstract}

Keywords: small-strain stiffness; ground improvement; ground remediation; local strain; triaxial test

\section{Introduction}

The Great East Japan earthquake of 2011 generated a huge quantity of disaster waste and tsunami deposits, which required proper treatment and disposal. To effectively use these waste soils in sustainable geotechnical infrastructures, it is essential to understand the mechanical behavior in their native (pure) or mechanically stabilized form (amended with cement and fiber). The small-strain stiffness of soil plays an important role in the sustainability of many geotechnical problems, such as machine foundations, earthquake ground response analysis, and liquefaction potential evaluations [1-3]. Several techniques have been developed in geotechnical engineering for measuring small-strain stiffness, including resonant columns [4,5], piezoelectric transducers [6-11], and quasi-static loading with high 
resolution strain measurements [12-15]. A widely used method to measure small-strains is the Hall effect local strain transducer [16]. This type local strain transducer has been employed in various research studies [17-19] to estimate small-strain stiffness moduli. The stress-strain curves observed in the conventional triaxial system are subjected to many errors, especially at small strain range, when the deformations are measured externally. The most common errors observed are seating errors, alignment errors, bedding errors, system compliance, and end restraints. Many researchers [16,20-29] have developed various on-sample strain measuring devices to measure the strains accurately and to compute stiffness at small strain levels. Most of the sophisticated devices reported above are used to estimate small-strains for clean sand specimens.

Laboratory and field testing have shown that the stress-strain behavior of sands can be highly nonlinear, even at stresses well below the peak strength of the material. One of the first comprehensive studies where the parameters that control nonlinear soil behavior were identified was the study by Hardin and Drnevich [30,31]. The empirical equations proposed by Hardin and Drnevich [31] account for the effects of plasticity index, overconsolidation ratio, and confining pressure mainly through adjusting reference strain. The effect of soil type, number of loading cycles, loading frequency, and saturation, amongst other aspects, have also been taken into consideration $[11,32,33]$. Iwasaki et al. [34] and Kokusho [12] studied the impact of confining pressure, but these studies were limited to observations on clean narrow graded sands tested at low pressures.

Michalowski and Cermak [35] reported that the initial stiffness of a composite material (e.g., sand and fiber) was affected by the different characteristics of the steel and polyamide fibers (e.g., stiffness, roughness, rigidity, size, etc.). Previous research with mixtures of steel fibers and sand [36] indicated that even larger fiber concentrations (e.g., $1.25 \%$ by volume) had no adverse effect on the initial stiffness. In addition, steel fiber had a reinforcement effect only slightly higher than less stiff polyamide fiber of the same geometry. It was further concluded that this difference might be attributed to a larger interfacial friction angle of steel fibers compared to polyamide fibers. In addition, it was reported that the strain levels or mobilization resistance for steel fiber (e.g., stiff) is greater than that of polyamide fibers (e.g., flexible) due to their greater stiffness. The literature review on cemented sand shows that natural or artificial cementation increases the small-strain stiffness behavior $\left(G_{0}\right)$ of sands [37-40]. Acar and El-Tahir [37] reported that shear modulus of cemented sands increased with confining stress in the applied range. Conversely, Sharma and Fahey [39] reported that small-strain stiffness $\left(G_{0}\right)$ to be for cemented sands practically independent of the mean stress and dependent on cementation until it was reached a threshold stress corresponding to the onset of major structure degradation. Yun and Santamarina [41] indicated for artificially cemented soils an increase of $G_{0}$ with increasing stress after yielding and the values of $G_{0}$ remained higher than for the reconstituted soils. Cementation appears to control only $G_{0}$ of clays below isotropic or vertical yield stress and the pressure dependency appears to prevail at higher stresses. The latter findings lead to the conclusion that the stiffness of the cemented soils is strongly increased by cementation and independent of confining pressure [40]. Mair [42] and Xu et. al. [43] proposed that the stiffness of a soil is constant below a strain level of $0.001 \%$ (e.g., $10^{-5}$ ) and reduces significantly with an increase in strain level (i.e., above $0.001 \%$ ). In recent decades, researchers have attempted to validate the approximate relationship between stiffness and strain level by employing different instruments, as shown in Figure 1.

Fahey and Carter [44] proposed a hyperbolic model to characterize modulus reduction as a function of shear strength mobilization, as seen in Equation (1). This function requires maximum shear stress $\left(\tau_{\max }\right)$ and an estimate of the small-strain shear modulus $\left(G_{0}\right)$ to be the value of shear modulus at shear strain of $10^{-6}$ and is assumed to be constant below this value, as well as empirical parameters $f$ and $g$. Fahey and Carter [44] showed some success fitting this three-parameter model to the data of a wide range of uncemented soils.

$$
\frac{G}{G_{0}}=1-f\left(\frac{\tau}{\tau_{\max }}\right)^{g}
$$


Darendeli [32] proposed a modified hyperbolic model based on testing of intact sand-gravel sample:

$$
\frac{G}{G_{0}}=\left[\frac{1}{\left(1+\gamma / \gamma_{r}\right)^{a}}\right]
$$

where $a$ is called the curvature parameter, and $\gamma_{r}$ is the reference strain value at which $G / G_{0}=0.50$. This model uses only two parameters, and the reference strain provides an efficient normalization of the shear strain. To better understand the non-linear elastic behavior of sands, and produce a generalized functional relationship, Oztoprak and Bolton [45] conducted a metastudy of the secant shear modulus degradation curves of 454 tests of uncemented sands from the literature. This curve-fitting process led to new interpretations and definitions that enable better predictions of the shear modulus degradation of sands with strain, based on soil classification data.

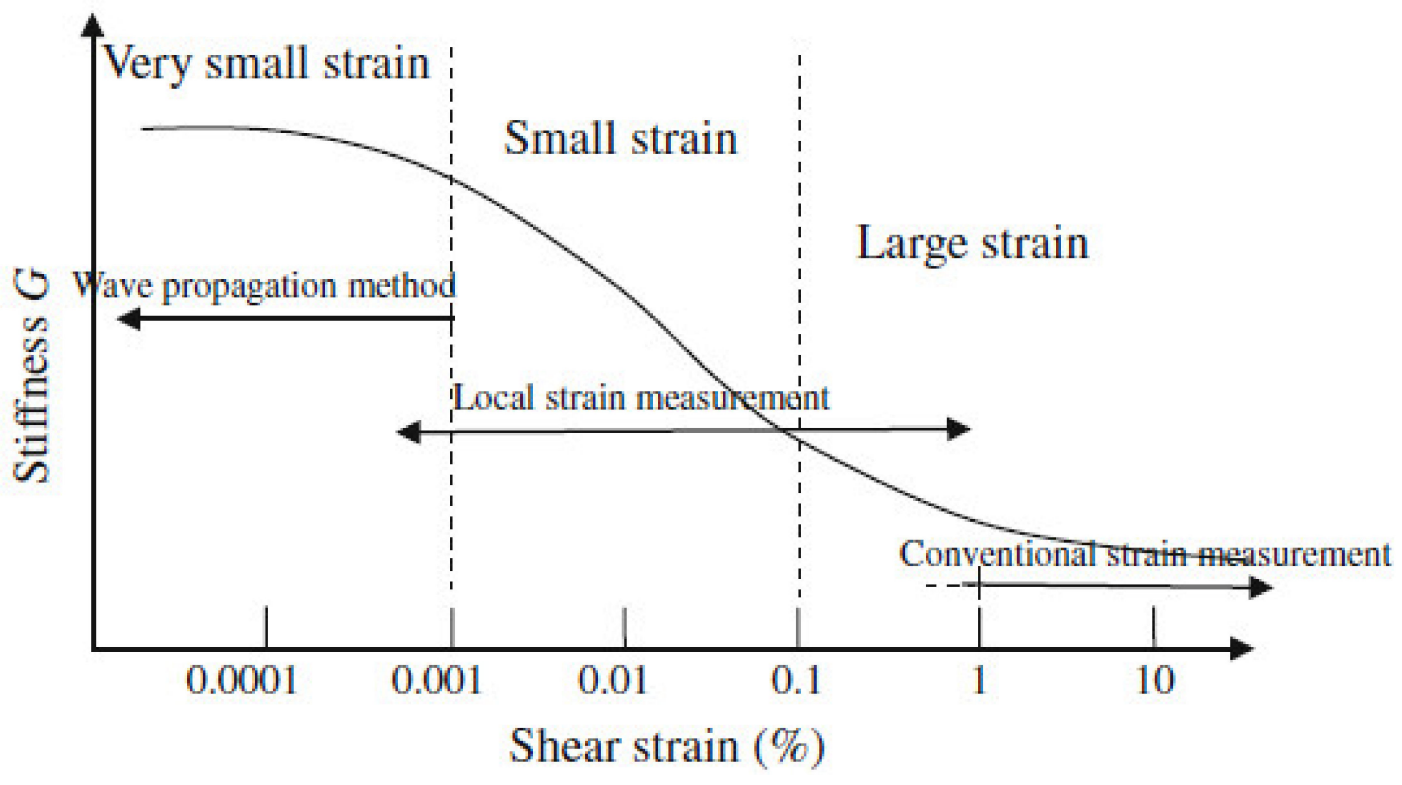

Figure 1. Typical modulus degradation measurement of soil stiffness in laboratory test (after Mair [42]).

In order to enhance the current database on small-strain stiffness behavior and stiffness degradation of amended soils, there is a need to further investigate the effect of fiber and cement additives on the small-strain stiffness $\left(G_{0}\right)$ of sands. In addition, the aim of the work is to develop a rational method and propose few modifications to the series of equations that can be used to evaluate the shear modulus and mobilized stress curves at small-strain levels. Furthermore, the experimental results of amended soils are compared with the Oztoprak and Bolton [45] upper bound and lower bound stiffness degradation models. The modified version of hyperbolic equation for amended soils (e.g., fiber-only, cement-only, and fiber-reinforced cemented sands) leads to a wide range of values for elastic threshold strain $\left(\gamma_{e}\right)$, the reference strain $\left(\gamma_{r}\right)$, and the range of curvature parameter $(a)$.

\section{Materials and Methods}

There has been ongoing long-term collaboration between Western University and Fukuoka University, Japan, with a view to improving those soils, utilizing waste streams and developing industry guidelines for construction. An in-depth coordinated laboratory program of the static and dynamic mechanical effects of various inclusions such as silt, different cementitious additives, and various types of fibers in Toyoura sand has been conducted at both universities over the last seven years. Initial studies on polyvinyl alcohol fiber (PVA) inclusions and Portland cement have been published [46-48] and results from the tests performed confirmed that the addition of polymer fibers and cement improved the liquefaction resistance, undrained shear strength, and stiffness of silty 
and unreinforced Toyoura sand. Further work on bamboo fibers, gypsum, and cement is currently being conducted in Japan. A comprehensive investigation of the strength and stiffness of these types of materials is vital to support the range of studies being conducted. The current study forms a part of this overall collaborative program with Fukuoka University and addresses this aspect of the work.

\subsection{Materials}

The three different types of materials e.g., Toyoura sand, polyvinyl alcohol (PVA) fibers, and ordinary Portland cement (OPC) were employed in this study to simulate the use of tsunami wastes in construction of sustainable geotechnical infrastructures. Toyoura sand is a Japanese benchmark sand, which is a well-known laboratory test sand. Toyoura sand has been previously used in a number of investigations and is composed of $75 \%$ quartz, $22 \%$ feldspar, and 3\% magnetite. It can be found primarily in the coastal regions of the Pacific Ocean in Japan $[49,50]$. The soil has a uniformity coefficient $\left(C_{u}\right)$ of 1.24 , a minimum void ratio $\left(e_{\min }\right)$ of 0.62 , and maximum void ratio $\left(e_{\max }\right)$ of 0.95 . Specific gravity test was performed on clean Toyoura sand according to ASTM standard [51] and the specific gravity value of 2.65 was determined. The specific gravity $(G s)$, like many silicate sands, ranges from 2.64-2.65 for pure Toyoura sand [46,48]. A typical grain size distribution of Toyoura sand is presented in Figure 2a. Toyoura sand is described as having angular to sub-angular particles, is fine grained and poorly graded, which is confirmed by the low coefficient of uniformity and coefficient of curvature, according to the classification of SP by the Unified Soil Classification System (USCS) $[46,52,53]$.

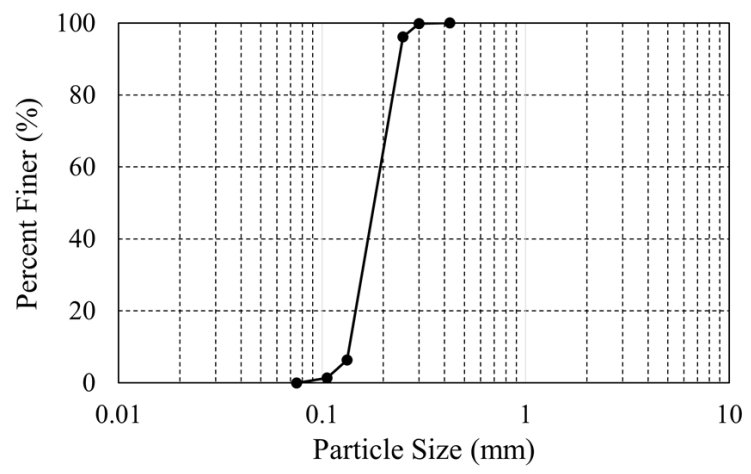

(a)

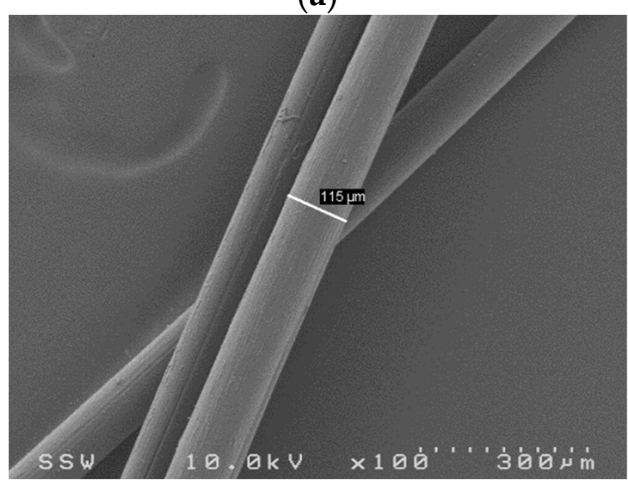

(c)

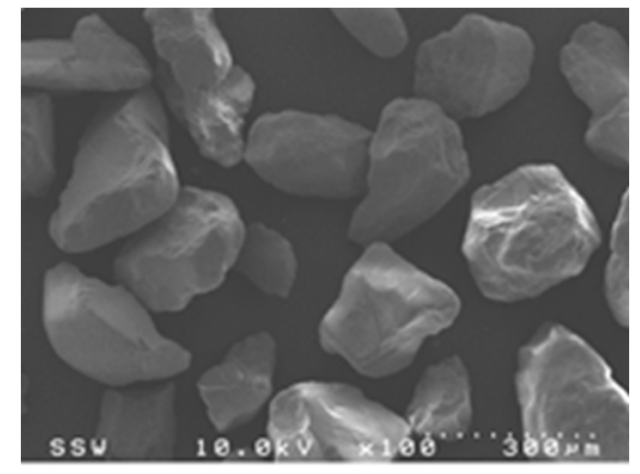

(b)

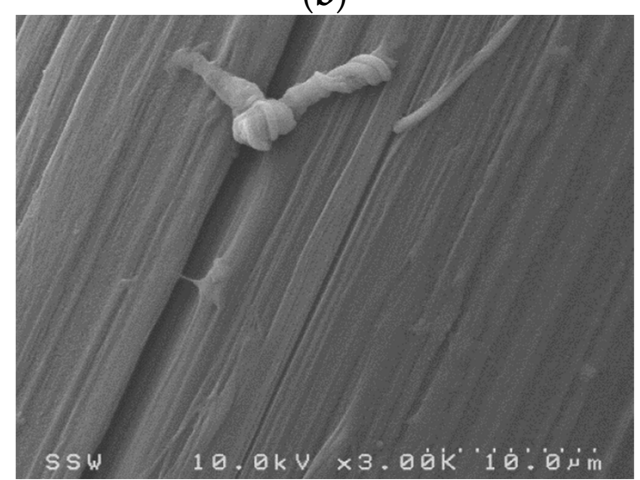

(d)

Figure 2. (a) Grain size distribution curve for Toyoura sand (b) Toyoura sand 100× optical zoom (c) PVA fiber 100× optical zoom (d) PVA fiber 3000× optical zoom (after Schmidt [50]).

Figure $2 \mathrm{~b}$ shows a scanning electron microscopic (SEM) image of Toyoura sand and provides an indication of the size, shape, and texture of the particles [46]. The Polyvinyl alcohol (PVA) fibers used in this study shown in Figure 2c have a specific gravity of 1.3. The PVA fibers have a Young's modulus of $28 \mathrm{GPa}$ and a tensile strength of $1200 \mathrm{MPa}$ (Kuraray Cooperation Limited, Tokyo, Japan). Figure $2 \mathrm{~d}$ shows micro-striations; these striations and filaments give the fibers a surface roughness and, with the 
existing angularity of the Toyoura sand, might also help in providing the necessary cementitious bonding. Nominal dimensions of the individual fibers are $12 \mathrm{~mm}$ long, with a diameter of $0.11 \mathrm{~mm}$. Ordinary Portland Cement Type-I (OPC-I) shipped from Ube-Mitsubishi Cement Corporation in Japan was used as a cementing agent and added as a percent by mass to each specimen. OPC-I has a specific gravity of 3.15 and a composition consisting of approximately $63 \%$ tricalcium silicate, $12 \%$ di-calcium silicate, $5 \%$ tri-calcium aluminate, and $11 \%$ tetra-calcium alumino-ferrite [54]. These cementitious and fibrous additives have been previously used to model the monotonic and cyclic properties of amended Toyoura sand [46-48].

\subsection{Sample Preparation, Testing Apparatus, Testing Procedure, and Testing Program}

The under-compaction moist tamping technique was employed for sample preparation [55]. Cylindrical specimens were formed in five layers with a height of $100 \mathrm{~mm}$ and a diameter of $50 \mathrm{~mm}$ [56]. Most of the samples were prepared to a target dry density value of $\rho_{d}=1.49 \mathrm{~g} / \mathrm{cm}^{3}$. This density was selected to replicate a field condition (i.e., medium dense state) for the compacted soil and for comparison with previously published studies [46,47]. Unreinforced, fiber-only, cement-only, and fiber-reinforced cemented Toyoura sand samples were prepared and mixed at 10 percent of water content by dry mass of soil. Figure 2 shows a local strain transducer mounted on a typical sample. All cemented samples were cured for 3 days. Two main reasons for 3 days curing duration used are:

1. The main reason for choosing the shorter curing duration is to speed up the testing process to investigate the effect of cementation on the small-large strain measurements. After three days of curing, an average degree of hydration of $88 \%$ is assumed based on empirical data [57].

2. The other reason is to find the lower bound behavior (short term strength and stiffness) of cemented sand. A shorter curing duration provides an initial estimate of strength and stiffness increases. Therefore, the short-term strength and stiffness increases are of vital importance for the design of several geotechnical problems (e.g., machine foundations, embankments etc.). Short curing duration and lower cement content, which are close to the field shallow mixing technique, might help geotechnical engineers in the determination of minimum stiffness and strength of composite materials. In addition, due to the improvements in the strength and stiffness of these amended materials (e.g., despite the short curing times, 0-3\% fiber and cement contents), this may be a viable strengthening method for dredged soils, disaster wastes and reclaimed land.

Past research on cemented sands has focused almost exclusively on longer curing durations (e.g., 7-28 days) and higher cement contents (e.g., 0-16\%). Overall, sand-cement-fiber composites have been observed to be more effective when specimens are cured for longer durations. These findings are likely to be due to a better contact between the sand-cement-fiber matrix bonding, cement hydration, and improved interaction due to a longer curing period. Limited studies are reported to determine the stiffness and strength of sand-cement-fiber composites for shorter curing duration (e.g., 3 days) and lower cement content (e.g., $0-3 \%$ by dry mass of soil). Hence, further laboratory investigations on lower cement content (e.g., $0-3 \%$ ) and short curing duration is essential in relation to field applications.

Table 1 summarizes the testing program used to evaluate the effect of fiber and cement content on the small-strain shear behavior. A unique test ID is used for the representation of a test i.e., LSM-COF0M0 represents local strain measurement $(\mathrm{LSM})$ for cement $(C)=0 \%$, fiber $(F)=0 \%$ and silt $(\mathrm{M})=0 \%$. A GDS triaxial apparatus was employed to conduct consolidated drained (CD) compression triaxial tests as per accordance to ASTM D7181 [55] to investigate the behavior of unreinforced, fiber-only, cement-only, and fiber-reinforced cemented Toyoura sand specimens. This system is a computer controlled, fully automated advanced GDS Triaxial Testing System (GDSTTS). The GDS Standard Level Pressure/Volume Controllers (STDDPC) allow for pressure measurements to be resolved to $1 \mathrm{kPa}$, with an accuracy of $\pm 1.5 \mathrm{kPa}$ up to a maximum pressure of $2 \mathrm{MPa}$. Volume changes can be resolved to $1 \mathrm{~mm} 3$ at an accuracy of $<0.25 \%$ of the current measurement. A $15 \mathrm{kN}$ load balanced internal load cell was installed providing an accuracy of $\pm 1 \mathrm{~N}$ [58]. Hall effect local strain transducers were mounted 
in the middle third of the sample (Figure 3), which is less restrained than the end zones. It is highly desirable that axial deformations are measured locally, if small deformations moduli are to be found. The range, resolution, and accuracy of Hall effect transducer is $\pm 0.3 \mathrm{~mm},<0.1 \mu \mathrm{m}$, and $0.2 \%$ respectively (GDS Instruments). Triaxial tests use external Linear Variable Differential Transformers (LVDTs) to measure large strains (e.g., 0.01-10\%). However, these LVDTs measure the global strain applied and not the local strain developed in the triaxial soil sample during shearing. Accurate determination of soil small-strain stiffness is difficult to achieve using global LVDTs attached to the actuator of automated triaxial system in routine laboratory testing. In this study, Hall effect local strain transducers are used to investigate the small-strain stiffness behavior of unreinforced, fiber, cemented, and fiber-reinforced cemented Toyoura sand specimens in triaxial tests.

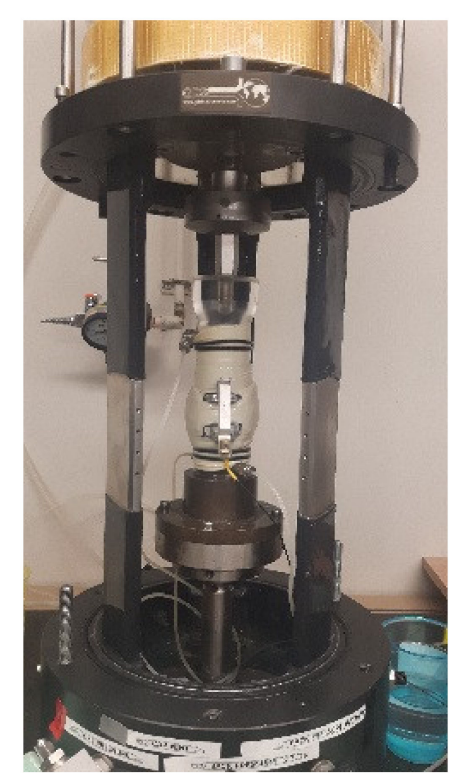

Figure 3. Hall effect local strain transducer mounted on a typical sample.

Table 1. Testing program for local strain measurements.

\begin{tabular}{|c|c|c|c|c|}
\hline Test No. & Test ID & Mean Effective Stress, $\mathrm{p}^{\prime}, \mathrm{kPa}$ & $\begin{array}{c}\text { Cement } \\
\text { Content, \% }\end{array}$ & Fiber Content, $\%$ \\
\hline 1. & LSM-COFOM0 & $\begin{array}{l}\text { Sand Only } \\
100 \\
\text { Fiber Only }\end{array}$ & 0 & 0 \\
\hline 2. & LSM-C0F0.5M0 & 100 & 0 & 0.5 \\
\hline 3. & LSM-C0F1M0 & 100 & 0 & 1 \\
\hline 4. & LSM-C0F2M0 & 100 & 0 & 2 \\
\hline & & Cement Only & & \\
\hline 5. & LSM-C1F0M0 & 100 & 1 & 0 \\
\hline 6. & LSM-C2F0M0 & 100 & 2 & 0 \\
\hline 7. & LSM-C3F0M0 & 100 & 3 & 0 \\
\hline 8. & LSM-C4FOM0 & 100 & 4 & 0 \\
\hline & & Fiber + Cement & & \\
\hline 9. & LSM-C3F1M0 & 100 & 3 & 1 \\
\hline 10. & LSM-C3F2M0 & 100 & 3 & 2 \\
\hline 11. & LSM-C3F3M0 & 100 & 3 & 3 \\
\hline 12. & LSM-C2F1M0 & 100 & 2 & 1 \\
\hline
\end{tabular}

All of the specimens were saturated with de-aired water and $\mathrm{CO}_{2}$ until a B-value of at least 0.96 was reached, before starting the consolidation stage. First, carbon dioxide $\left(\mathrm{CO}_{2}\right)$ was slowly flushed through the bottom of the sample for about $30 \mathrm{~min}$ to absorb any entrapped air in the voids of specimen 
with a gradient of pressure for approximately $3 \mathrm{kPa}$. The top and bottom drainage lines were flushed with de-aired water through back pressure pump at a very slow rate. After flushing the drainage lines, the de-aired water was flushed in the specimen at a very slow rate to fill the voids of specimen and replace $\mathrm{CO}_{2}$. In addition, the pore water pressure values were also monitored during $\mathrm{CO}_{2}$ percolation and flushing with water. It was necessary to maintain an effective stress of approximately $3 \mathrm{kPa}$ in order to minimize any sample disturbance. Once the $\mathrm{CO}_{2}$ percolation and flushing with water was finished, the cell pressure was ramped to $320 \mathrm{kPa}$ and back pressure was ramped to $310 \mathrm{kPa}$, maintaining an effective stress of $10 \mathrm{kPa}$. In the next stage, cell pressure was then ramped to $330 \mathrm{kPa}$ (e.g., the back pressure $310 \mathrm{kPa}$ was kept constant and cell pressure starting at $320 \mathrm{kPa}$ was then increased at a rate of $2-3 \mathrm{kPa} /$ minute, till the final target cell pressure of $330 \mathrm{kPa}$ was reached) and pore pressure coefficient $\mathrm{B}$ was checked during the saturation stage. Higher B-values were possible in the cemented samples due to the application of higher back pressures (e.g., $320 \mathrm{kPa}$ ), short curing duration (e.g., 3 days), and lower cement contents (0-3\%). All of specimens for the consolidated drained (CD) tests were isotropically consolidated to the desired mean effective stress (e.g., $100 \mathrm{kPa}$ ) under computer control. The consolidation stage was continued until $100 \%$ primary consolidation was reached. The rate of axial displacement used to shear all of the specimens was $0.06 \mathrm{~mm} / \mathrm{min}[46,48,59]$ to eliminate any concerns over rate effects, when comparing the results.

\section{Results and Discussion}

Typical deviator stress versus shear strain and mobilized stress $\left(\frac{q}{q_{p k}}\right)$ curves obtained from the Hall effect local strain transducer under drained triaxial shear are shown in Figures 4 and 5. Where, $q=$ deviator stress is the difference between the major and minor principal stresses in a triaxial test, which is equal to the axial load applied to the specimen divided by the cross-sectional area of the specimen, $q_{p k}=$ peak deviator stress, $\frac{q}{q_{p k}}=$ mobilized stress developed with increase in shear strain. It can be seen that the small-strain stiffness (e.g., reference strain range $=0.001-0.05 \%$ ) reduces and the curve shows slightly flattened response compared to sand only specimen, with the addition of only fibers (Figure 4 b). In contrast, the small-large strain stiffness (e.g., reference strain range $=0.1-1.0 \%$ ) increases by up to $0-137 \%$ (Figure $4 a$ ); similar results were reported in previous studies [36,60-62] and this behavior is a consequence of the loss of contact between the particles and a reduction in the particle-to-particle friction due to the presence of the fibers [63]. In contrast to the fiber-only specimen, the addition of cement enhances the small-strain stiffness (e.g., reference strain range $=0.01-0.1 \%$ ) compared to sand only specimen of the Toyoura sand specimens by up to $160-171 \%$ (Figure $4 \mathrm{~b}$ ). Furthermore, the small-large strain stiffness (e.g., reference strain range $=0.1-1.0 \%$ ) increases by up to $175-158 \%$ (Figure 4a). Similar results were also reported by Consoli et al. [64] and Schnaid et al. [65]. These results highlight that the weak cementation (e.g., 3 days curing) induced is sufficient to moderately increase the small-strain stiffness and the curve shows relatively stiffer response [66]. In addition, fiber-reinforced cemented sand specimen showed an approximately $145-257 \%$ increase in small-strain stiffness (e.g., reference strain range $=0.01-0.1 \%$ ) behavior compared to the unreinforced specimens (Figure $4 \mathrm{~b}$ ). Furthermore, the small-large strain stiffness (e.g., reference strain range $=$ $0.1-1.0 \%$ ) increases by up to $260-265 \%$ (Figure $4 a$ ) and the curve shows significantly stiffer response compared to sand only specimen.

The results reported for fiber-reinforced cemented sand agrees well with previous studies [46-48,67]. The significant increase in small-large strain stiffness (e.g., reference strain range $=0.01-1.0 \%$ ) of fiberreinforced cemented sand is attributed to interparticle bonds, particle-to-particle contacts, and fiberparticle friction mechanism.

Figure 5a shows significant reduction in the mobilized stresses (e.g., reference strain range $=0.001-1.0 \%$ ) and the curves show slightly flattened response compared to sand only specimen, with the addition of only fibers (Figure $5 \mathrm{a}$ ). In contrast to fiber-only specimens, the mobilized stresses (e.g., reference strain range $=0.05-0.7 \%$ ) slightly increases (Figure $5 b$ ) for cement-only specimens (except for the $1 \%$ cement-only specimen). In addition, the fiber-reinforced cemented sand specimen 
showed limited increases in mobilized stresses (e.g., reference strain range $=0.01-0.1 \%$ ) compared to the unreinforced specimen (Figure $5 c$ ). However, Figure $5 c$ shows moderate increases in mobilized stresses (e.g., reference strain range $=0.1-0.5 \%$ ) compared to the sand-only specimen.

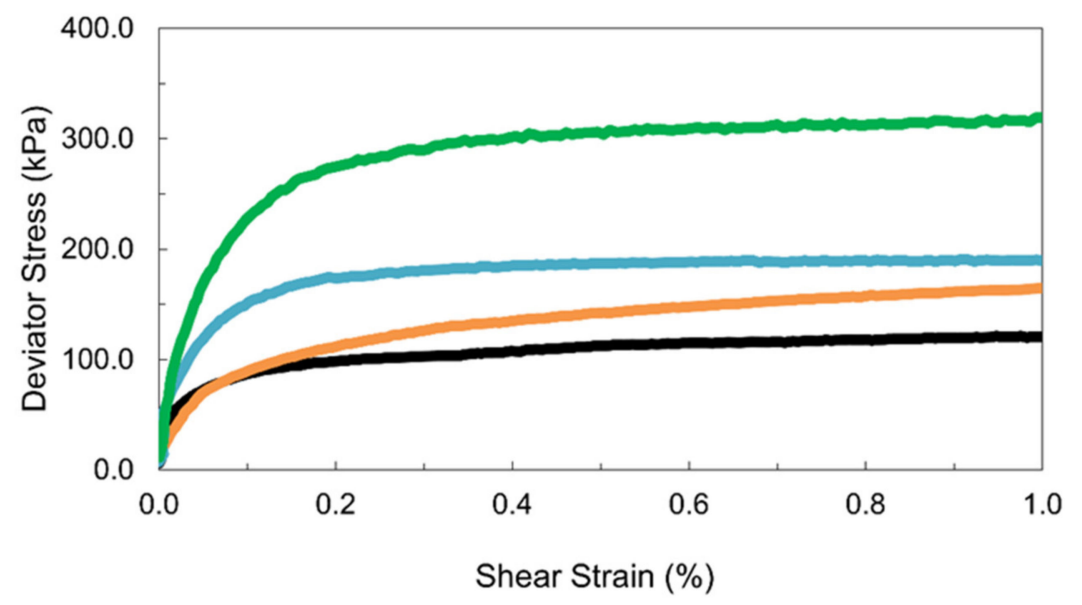

$-0 \% \quad-1 \%$ Fiber $\quad 3 \%$ Cement $\quad 3 \%$ Cement $+3 \%$ Fiber

(a)

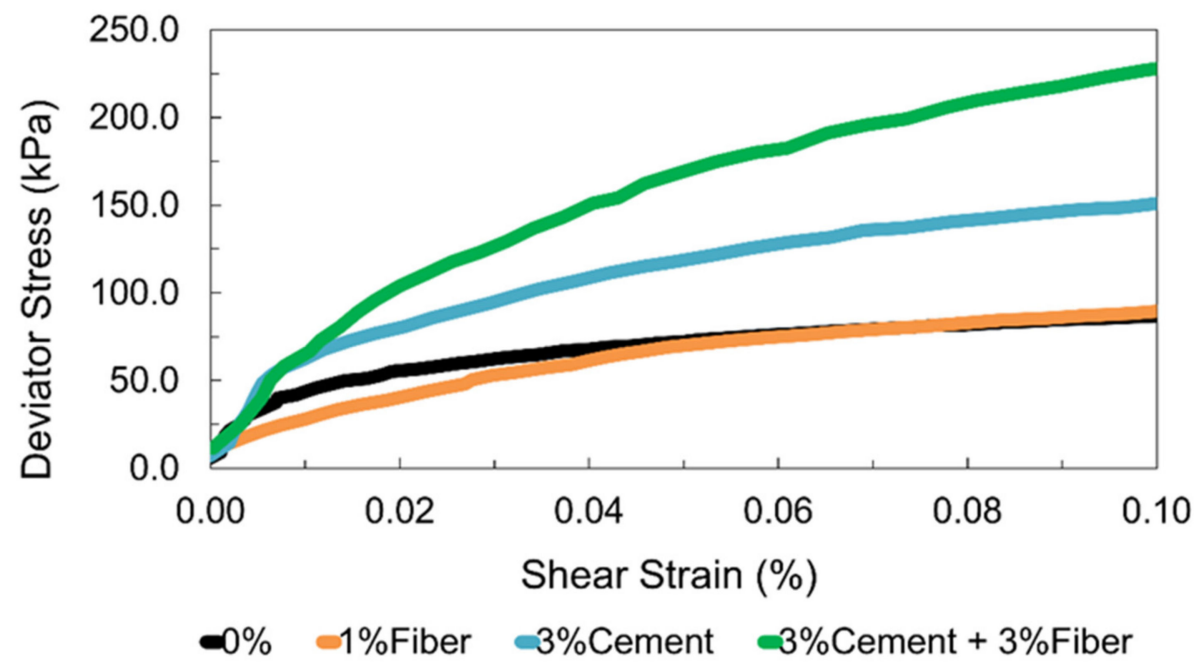

(b)

Figure 4. (a) Deviatoric stress $(q)$ versus shear strain $\left(\varepsilon_{q}\right)$ curves from drained triaxial tests for various Toyoura sand specimens $\left(\sigma_{c}^{\prime}=100 \mathrm{kPa}\right)(\mathbf{b})$ Zoomed in until $0.10 \%$ shear strain.

Figure 6a,c shows the normalized shear modulus reduction $\left(G / G_{i}\right)$ versus mobilized stress $\left(\frac{q}{q_{p k}}\right)$ curves. Where, $G=$ shear modulus at any shear strain level and $G_{i}=$ initial shear modulus. The value of initial shear modulus $\left(G_{i}\right)$ is obtained from the range of local strain measurements (e.g., reference strain, $\gamma_{r}=0.00013 \%$ to $0.00024 \%$ ). Fahey and Carter [44] presented similar test results in terms of modulus reduction versus mobilized stress for uncemented granular soils. They proposed a simple hyperbolic relationship for clean sands with a limited range of exponents (0.2-0.4) as shown below:

$$
\frac{G}{G_{0}}=\left[1-\left(q / q_{p k}\right]^{g}\right.
$$


where $G / G_{0}=$ shear modulus reduction, $\frac{q}{q_{p k}}=$ mobilized stress and $g=$ an exponent to encompass laboratory test data.

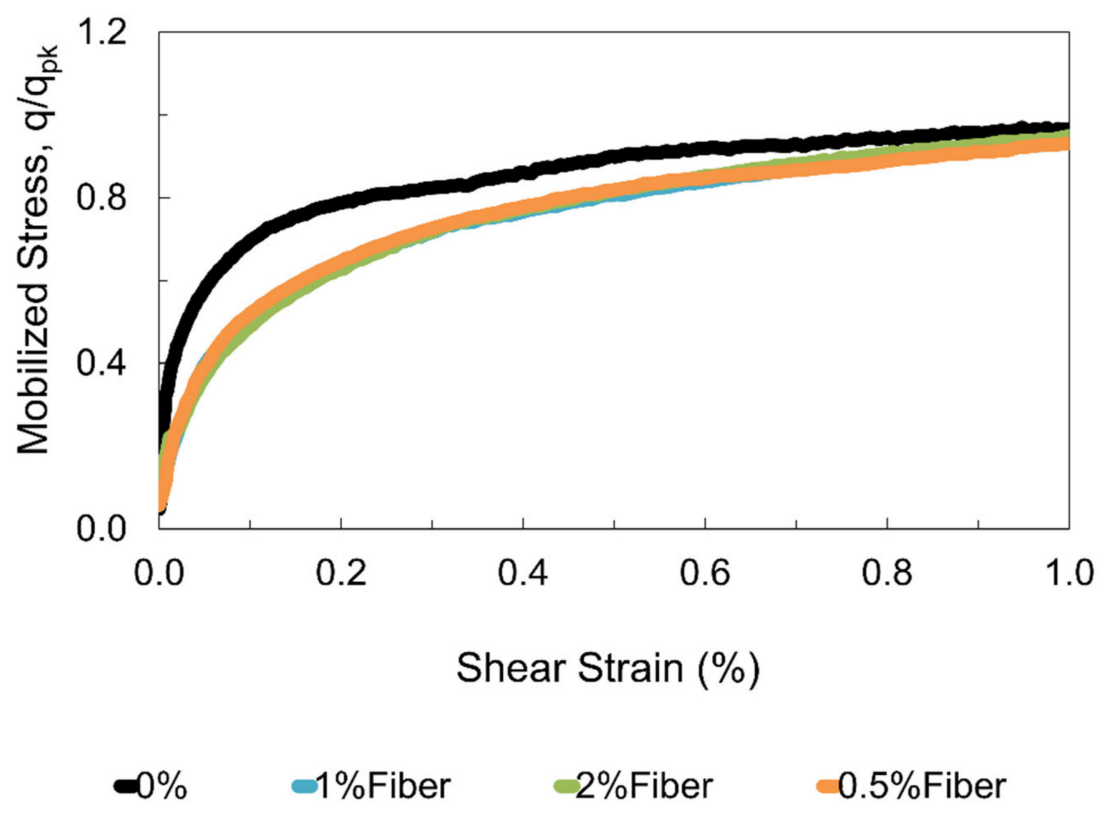

(a)

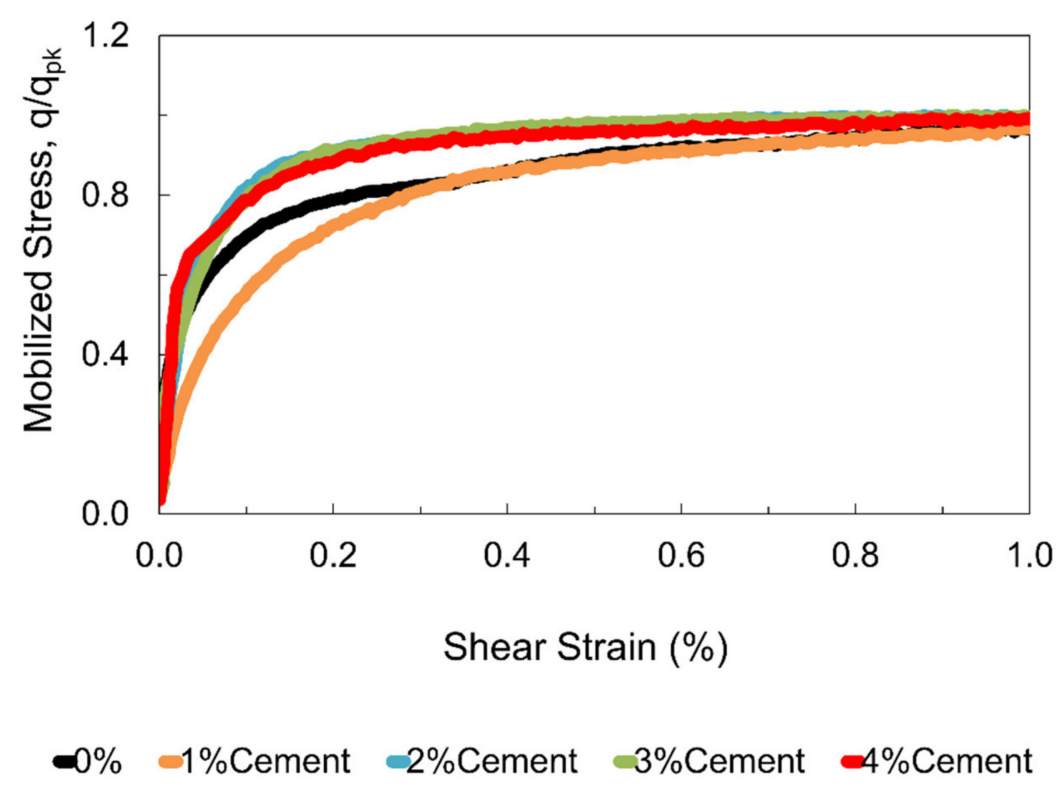

(b)

Figure 5. Cont. 


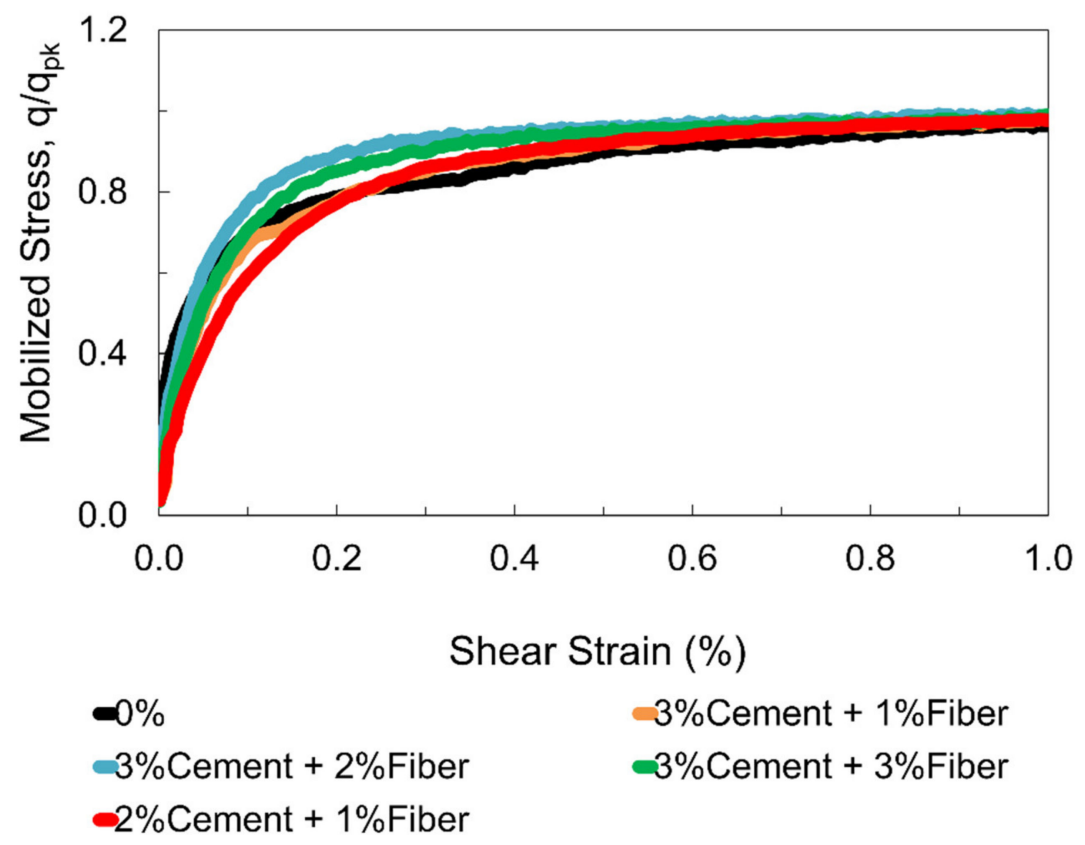

(c)

Figure 5. Mobilized stress $\left(\frac{q}{q_{p k}}\right)$ versus shear strain $\left(\varepsilon_{q}\right)$ curves from drained compression tests for various Toyoura sand specimens $\left(\sigma_{c}^{\prime}=100 \mathrm{kPa}\right)(\mathbf{a})$ Fiber only (b) Cement only (c) Cement + Fiber.

For pure Toyoura sand and fiber-only reinforced sand, it can be seen that the results agree well with the hyperbolic model (Equation (3)) employing an exponent value of $0.2-0.3$. For purely cemented sand, the results show close agreement adopting values in the range of 0.3-0.4. However, a slightly greater value of exponent (e.g., 0.4-0.6) is required to fit the results of the fiber-reinforced cemented sand. A range of exponent, $g=0.2-0.4$ was suggested by Fahey and Carter [44] for uncemented granular soils. In contrast, it can be seen that for cemented and fiber-reinforced sands, the range of exponent lies between 0.3 and 0.6 , showing a more intense decay of stiffness with straining.

Oztoprak and Bolton [45] proposed a generic relationship for the $G / G_{0}$ versus shear strain $\left(\varepsilon_{q}\right)$ curves based on a database of 454 tests from the literature. Three curve fitting parameters control the shape of the curve (see Equation (4)): (1) an elastic threshold strain $\left(\gamma_{e}\right)$, up to which the elastic shear modulus is constant at $G_{0}$, and which enables the expression to cover cementation and interlocking effects at small-strains; (2) a reference strain $\left(\gamma_{r}\right)$, the shear strain at which the secant modulus reduces to $0.5 G_{0}$-the two characteristic strains were found to vary with sand type (e.g., uniformity coefficient), state of the soil (e.g., void ratio, relative density), and mean effective stress; and lastly, (3) a curvature parameter $(a)$, which controls the rate of modulus reduction. An average value of curvature parameter, $a=0.88$, was employed for a database of 379 tests on uncemented sands.

$$
\frac{G}{G_{0}}=\frac{1}{1+\left[\frac{\gamma-\gamma_{e}}{\gamma_{r}}\right]^{a}}
$$

where $\gamma_{e}=$ elastic threshold strain, $\gamma_{r}=$ reference strain, and $a=$ curvature parameter.

Figures 7-9 show $G / G_{i}$ versus shear strain $\left(\varepsilon_{q}\right)$ curves from similar drained triaxial tests at varying cement (1-4\%) and fiber (0.5-3\%) contents. Table 2 shows the values of best-fit parameters proposed by Oztoprak and Bolton [45] and for unreinforced and reinforced Toyoura sand. 


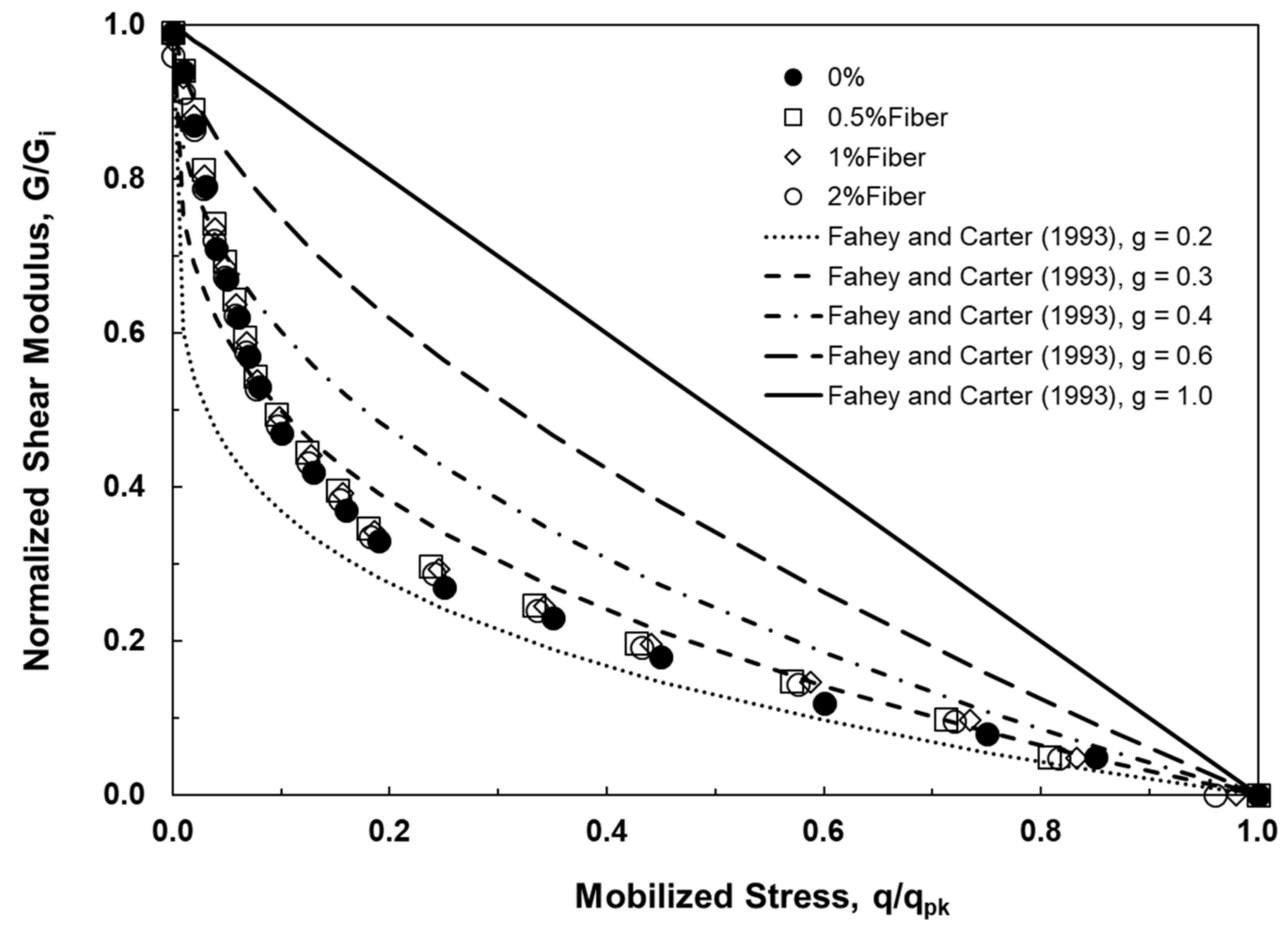

(a)

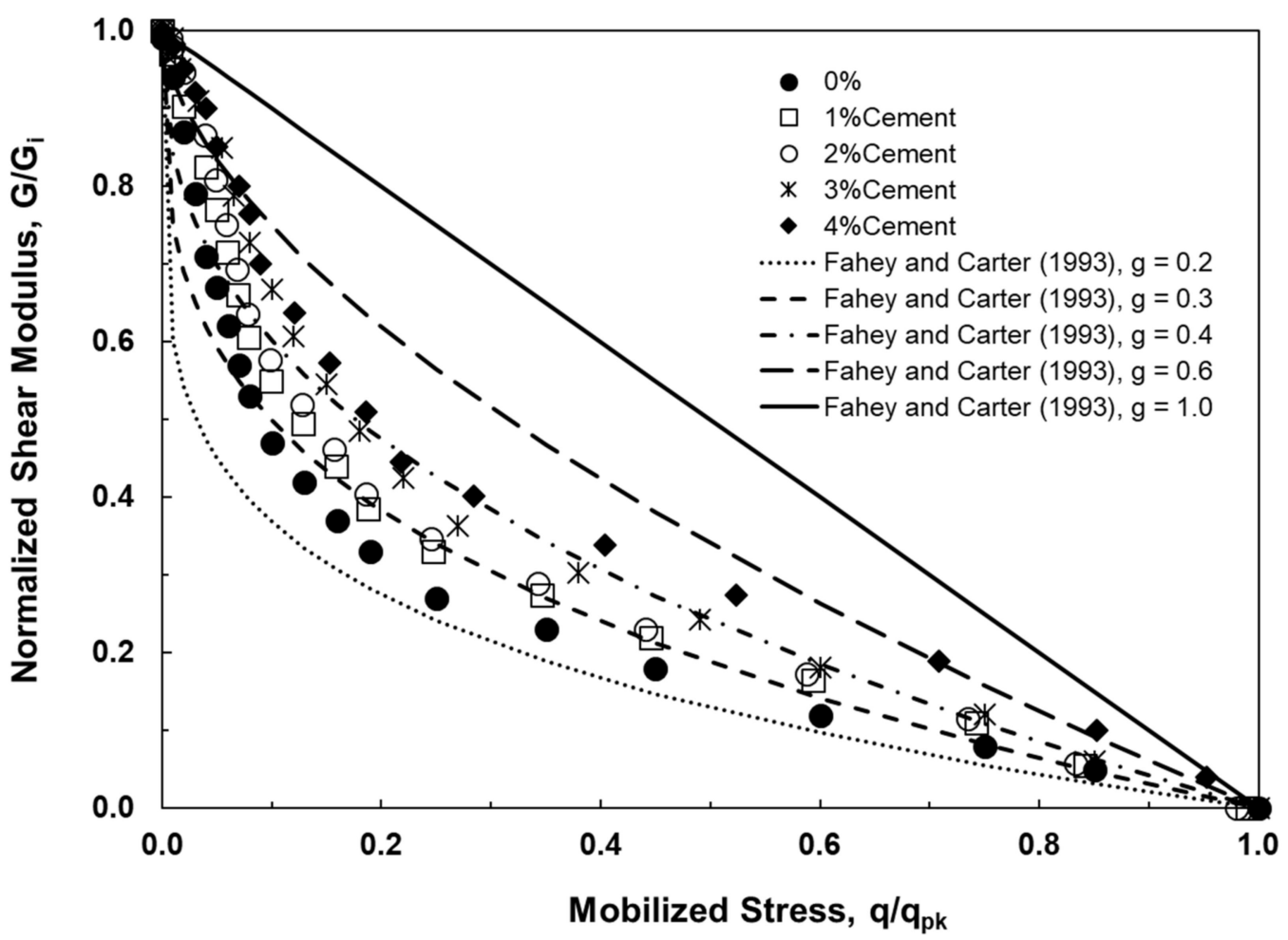

(b)

Figure 6. Cont. 


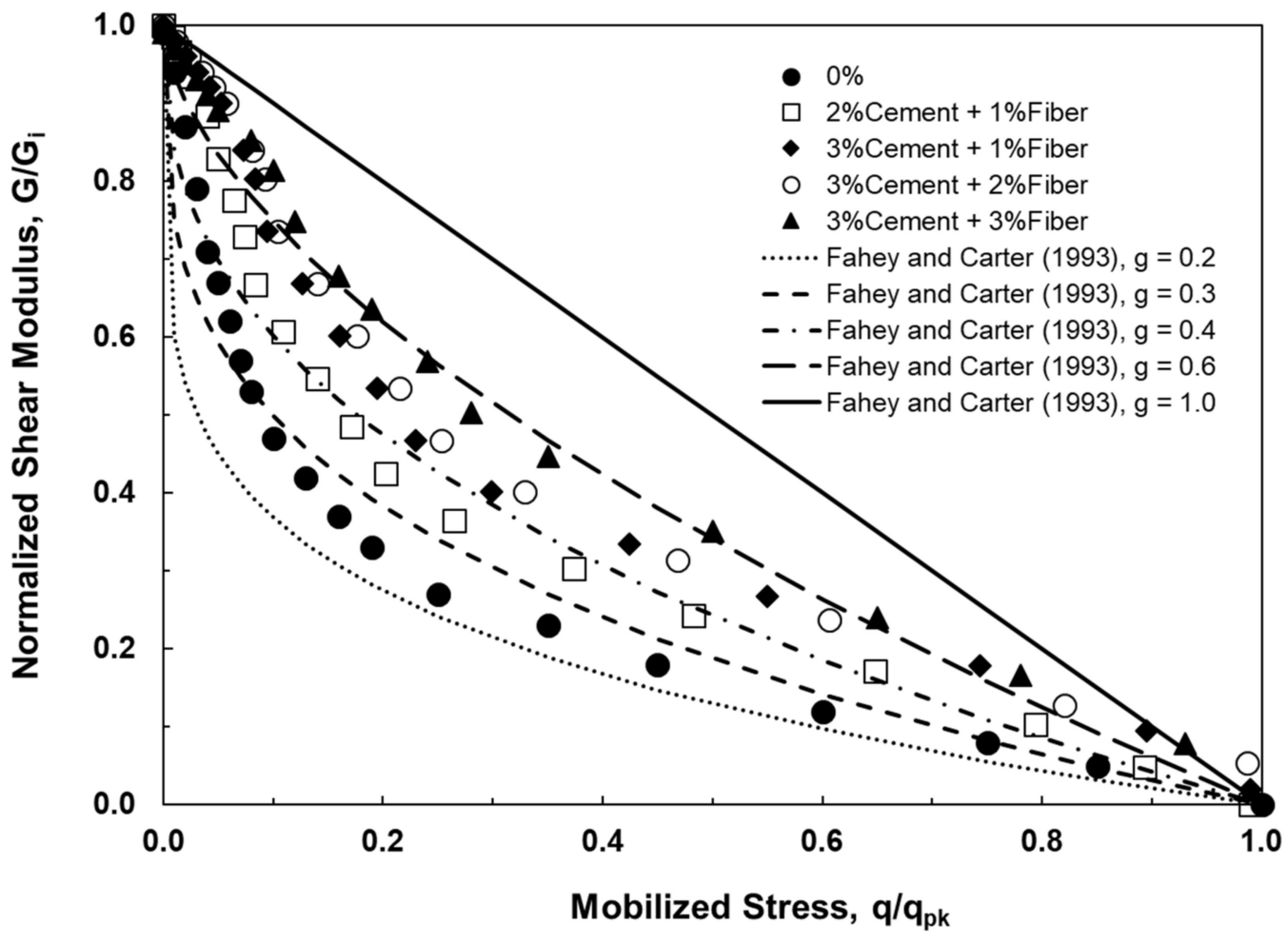

(c)

Figure 6. Shear modulus reduction $\left(G / G_{i}\right)$ versus mobilized stress $\left(\frac{q}{q_{p k}}\right)$ curves from drained compression tests for various Toyoura sand specimens $\left(\sigma_{c}^{\prime}=100 \mathrm{kPa}\right)$. (a) Pure Sand, and 0-2\% Fibers; (b) Pure Sand, and 0-4\%; (c) Pure Sand, 0-3\% Cement and 0-3\% Fibers.

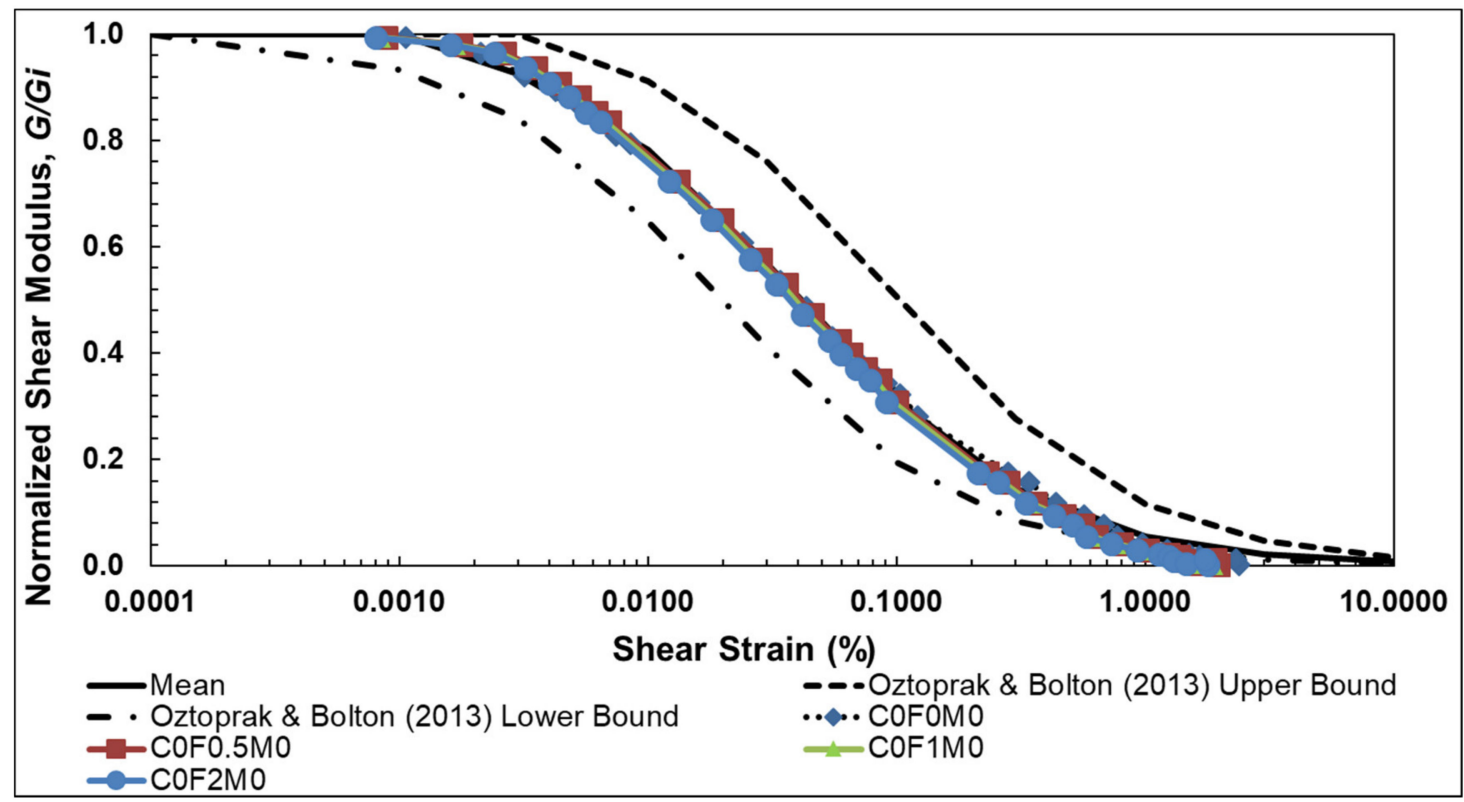

Figure 7. Pure Sand, and $0.5-2 \%$ Fibers. $G / G_{i}$ versus shear strain $\left(\varepsilon_{q}\right)$ curves from $C D$ compression tests for unreinforced and fiber-reinforced Toyoura sand specimens consolidated to $100 \mathrm{kPa}$ mean effective stress at different fiber contents $(0-2 \%)$. 


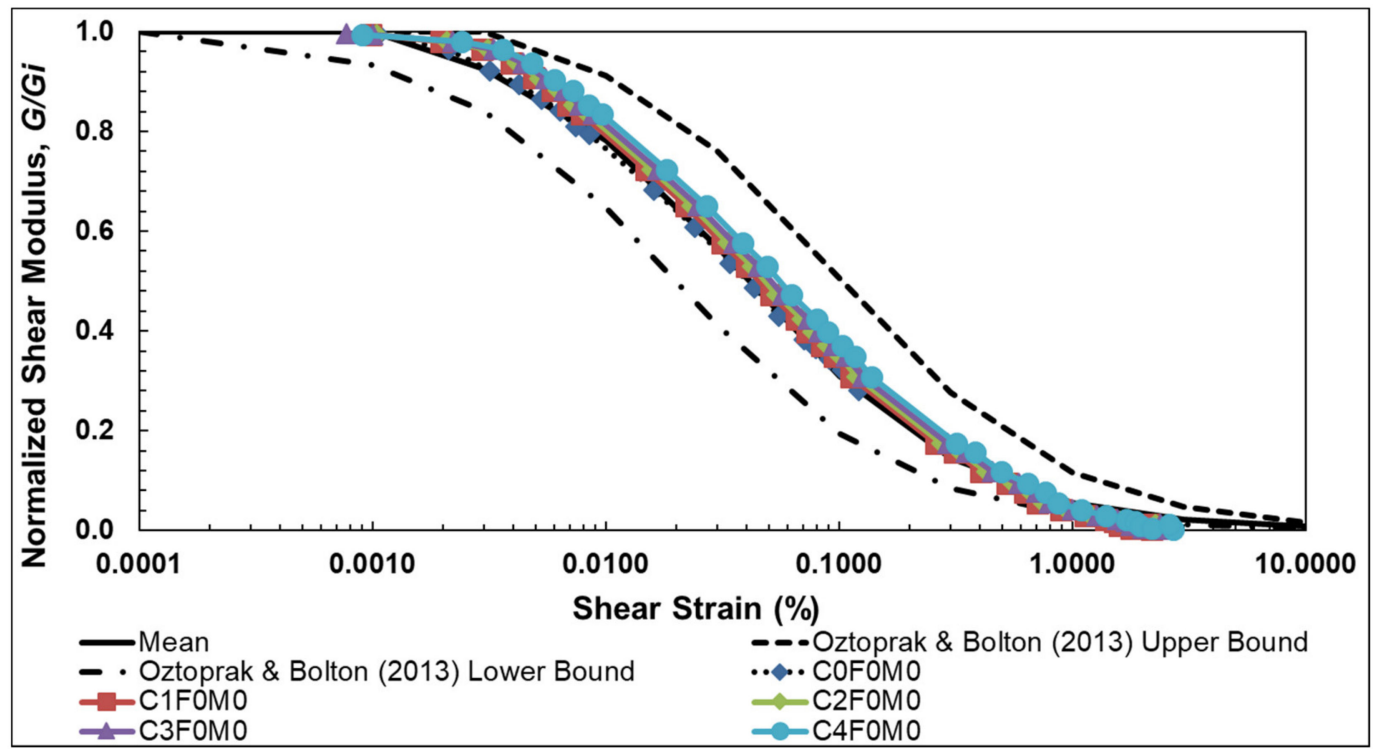

Figure 8. Pure Sand, and $1-4 \%$ Cement. $G / G_{i}$ versus shear strain $\left(\varepsilon_{q}\right)$ curves from CD compression tests for unreinforced and cemented Toyoura sand specimens consolidated to $100 \mathrm{kPa}$ mean effective stress at different cement contents $(0-4 \%)$.

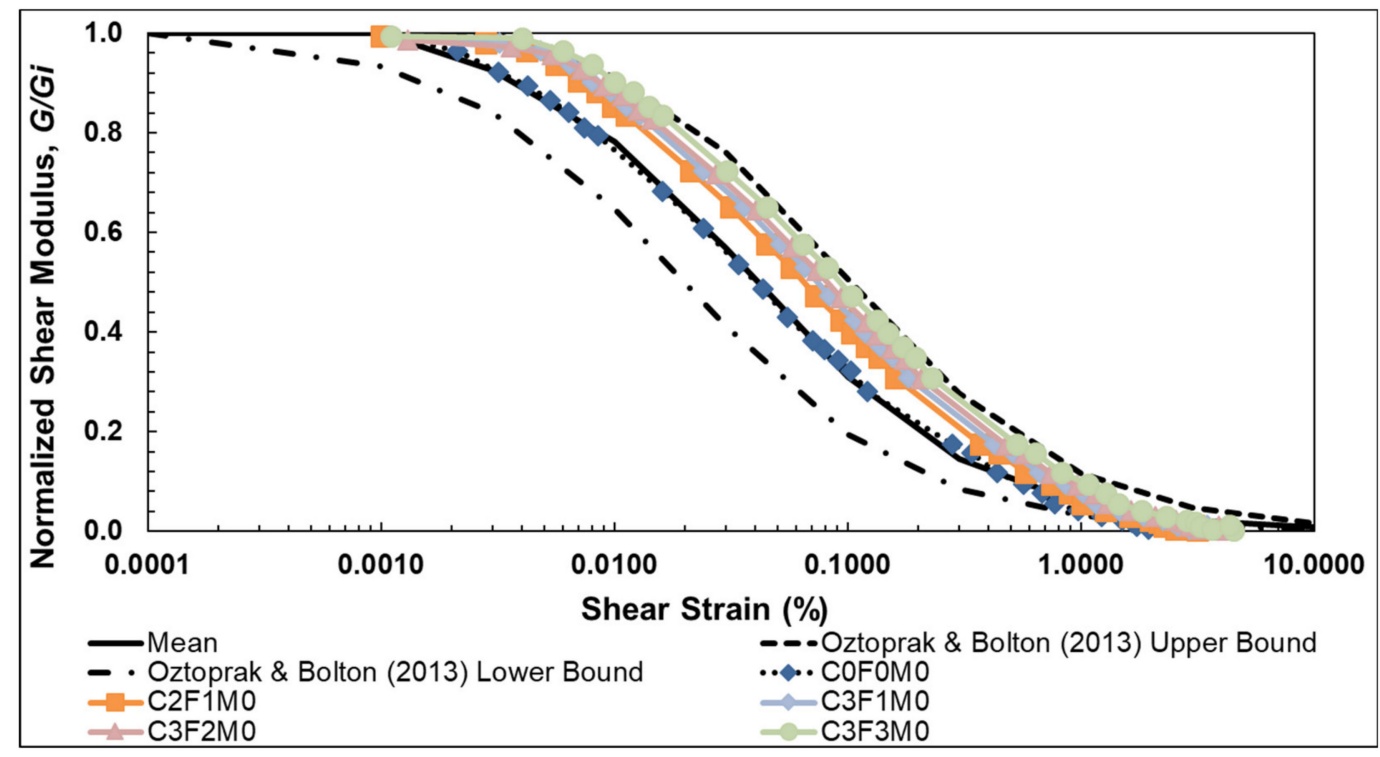

Figure 9. Pure Sand, $2-3 \%$ Cement and $1-3 \%$ Fibers. $G / G_{i}$ versus shear strain $\left(\varepsilon_{q}\right)$ curves from CD compression tests for unreinforced and fiber-reinforced cemented Toyoura sand specimens consolidated to $100 \mathrm{kPa}$ mean effective stress at different cement (0-3\%) and fiber $(0-3 \%)$ contents.

It can be seen in Figure 7 that the elastic threshold strain $\left(\gamma_{e}\right)$ ranges from $0.0007 \%$ to $0.001 \%$ for unreinforced and fiber-reinforced sand. This range slightly increases to $0.0009-0.0014 \%$ for cemented sand, shown in Figure 8. For the fiber-reinforced cemented sand shown in Figure 9, the threshold strain increases to a range of $0.0015-0.0022 \%$. The ranges for the reference strain $\left(\gamma_{r}\right)$, for unreinforced and fiber-reinforced sand $(0.039-0.043 \%)$, cemented sand $(0.048-0.056 \%)$, and fiber-reinforced cemented sand $(0.065-0.08 \%)$ are also shown in Table 2 . In addition, it can be seen that the curvature parameter (a) for unreinforced and fiber-reinforced sand was 0.88 , and 1.0 for cemented and fiber-reinforced cemented sand. The range of curvature parameter from 0.88 to 1.0 provides a good comparison with the results of local strain. Overall, the comparison of the results and model shows that the small-strain results obtained using local strain transducers fall within the range of model upper and lower bound 
curves. The results of the unreinforced, fiber-reinforced, and cemented sand shows a close agreement with the model mean curve, but fiber-reinforced cemented sand shows a good comparison with model upper bound.

Table 2. Comparison of curve-fitting parameters for unreinforced and reinforced Toyoura Sand with Oztoprak and Bolton [45].

\begin{tabular}{cccc}
\hline Sample ID & Elastic Threshold Strain, $\gamma_{\boldsymbol{e}}$ & Reference Strain, $\gamma_{\boldsymbol{r}}$ & Curvature Parameters, $\boldsymbol{a}$ \\
\hline C0F0M0 & 0.001 & 0.043 & 0.88 \\
C0F0.5M0 & 0.0008 & 0.042 & 0.88 \\
C0F1M0 & 0.0007 & 0.040 & 0.88 \\
C0F2M0 & 0.0007 & 0.039 & 0.88 \\
C1F0M0 & 0.0009 & 0.048 & 1 \\
C2F0M0 & 0.001 & 0.050 & 1 \\
C3F0M0 & 0.0012 & 0.052 & 1 \\
C4F0M0 & 0.0014 & 0.056 & 1 \\
C2F1M0 & 0.0015 & 0.065 & 1 \\
C3F1M0 & 0.0018 & 0.074 & 1 \\
C3F2M0 & 0.0020 & 0.076 & 1 \\
C3F3M0 & 0.0022 & 0.080 & 1 \\
Lower Bound & 0 & Oztoprak and Bolton $[45]$ & 0.88 \\
Mean & 0 & 0.02 & 0.88 \\
Upper Bound & 0.0007 & 0.044 & 0.88 \\
\hline
\end{tabular}

\section{Summary and Conclusions}

In this study, an effort has been made to utilize the tsunami waste as a ground improvement and remediation technique to build sustainable geotechnical infrastructures. Therefore, a series of local strain measurements were obtained on unreinforced, fiber, cemented, and fiber-reinforced cemented Toyoura sand specimens. It is shown that small-strain stiffness slightly reduces with the addition of fibers. In contrast, addition of cement enhances the small-strain stiffness properties of pure Toyoura sand specimens. The results highlighted that the weak cementation level (e.g., 3 days curing) induced by chemical treatment was sufficient to moderately increase the small-strain stiffness. In addition, fiber-reinforced cemented sand specimens showed increases in small-strain stiffness compared to unreinforced specimens. The fiber used in this study vary in diameter from 110-120 $\mu \mathrm{m}$, with striation widths of $5 \mu \mathrm{m}$ to less than $1 \mu \mathrm{m}$ along the $12 \mathrm{~mm}$ length. These micro-striations have small filaments protruding from them, which is likely a result of the extrusion process used in their fabrication. These striations and filaments give the fibers a rough surface and, with the existing angularity of the Toyoura sand, provide an ideal medium for cementitious bonding $[46,48,68,69]$. Results of the modulus degradation and mobilized stress curves show good agreement with the hyperbolic relation proposed by Fahey and Carter [44]. The comparison of the results with Oztoprak and Bolton [45] model shows that the results of the local strain transducers fall within the range of model upper and lower bound curves. The short curing duration and lower cement content with fiber additive shows close relevance to the field shallow mixing technique. The current research related to increase in stiffness parameters due to the combined effect of cement and fiber additives might be useful for the practicing engineers in the construction of economical and sustainable geotechnical infrastructures. In addition, the results show promising improvements in the strength and stiffness characteristics of fiber-reinforced cemented sand. Hence, much of the debris (such as concrete products, natural and polymeric fibers, and tsunami deposits on the coast of Japan) can be recycled in economical and sustainable geotechnical engineering projects, such as road embankments, recreational park restoration, and agricultural field restoration around the Tokyo Bay region $[47,48]$. 
Author Contributions: Conceptualization and methodology, M.S., T.N., K.S., and T.F.; investigation and analysis, M.S. and C.S.; writing — original draft preparation, M.S. and F.S.; writing—review and editing, M.S., T.N., and C.S.; supervision, T.N. All authors have read and agreed to the published version of the manuscript.

Funding: The research project was financially supported by the Western Graduate Research Scholarship at the Department of Civil and Environmental Engineering, Western University, London, Ontario, Canada.

Acknowledgments: The authors would like to acknowledge Miho Nakamichi, Shintaro Koga, and Hiromitsu Shiina for their technical support and for financial support for providing Toyoura Sand for the research project.

Conflicts of Interest: The authors declare no conflict of interest.

\section{References}

1. Richart, J.E., Jr.; Hall,J.R., Jr.; Woods, R.O. Vibrations of Soils and Foundations, 1st ed.; Prentice Hall: Upper Saddle River, NJ, USA, 1970.

2. Andrus, R.D.; Stokoe, K.H., II. Liquefaction resistance of soils from shear wave velocity. J. Geotech. Geoenviron. Eng. 2000, 126, 1943-5606. [CrossRef]

3. Yang, J.; Yan, X.R. Site response to multi-directional earthquake loading: A practical procedure. Soil Dyn. Earthq. Eng. 2009, 29, 710-721. [CrossRef]

4. Hardin, B.O.; Richart, F.E. Elastic wave velocities in granular soils. J. Soil Mech. Found. Div. 1963, 89, 39-56.

5. Cascante, G.; Santamarina, C.; Yassir, N. Flexural excitation in a standard torsional resonant column device. Can. Geotech. J. 1998, 35, 478-490. [CrossRef]

6. Brignoli, E.G.M.; Gotti, M.; Stokoe, K.H., II. Measurement of shear waves in laboratory specimens by means of piezoelectric transducers. Geotech. Test. J. 1996, 19, 384-397. [CrossRef]

7. Nakagawa, K.; Soga, K.; Mitchell, J.K. Observation of Biot compressional wave of the second kind in granular soils. Géotechnique 1997, 47, 133-147. [CrossRef]

8. Lings, M.L.; Greening, P.D. A novel bender/extender element for soil testing. Géotechnique 2001, 51, $713-717$. [CrossRef]

9. Kumar, J.; Madhusudhan, B.N. Effect of relative density and confining pressure on Poisson ratio from bender-extender element tests. Géotechnique 2010, 60, 561-567. [CrossRef]

10. Murillo, C.; Sharifipour, M.; Caicedo, B.; Thorel, L.; Dano, C. Elastic parameters of intermediate soils based on bender-extender elements pulse tests. Soils Found 2011, 51, 637-649. [CrossRef]

11. Ahmad, S. Piezoelectric Device for Measuring Shear Wave Velocity of Soils and Evaluation of Low and High Strain Shear Modulus. Ph.D. Thesis, Western University, London, ON, Canada, 3 February 2016.

12. Kokusho, T. Cyclic triaxial test of dynamic soil properties for wide strain range. Soils Found. 1980, 20 , 45-60. [CrossRef]

13. Hoque, E.; Tatsuoka, F. Anisotropy in elastic deformation of granular materials. Soils Found. 1998, 38, 163-179. [CrossRef]

14. Ezaoui, A.; Benedetto, H.D. Experimental measurements of the global anisotropic elastic behavior of dry Hostun sand during triaxial tests, and the effect of sample preparation. Géotechnique 2009, 59, 621-635. [CrossRef]

15. Gu, X.; Yang, J.; Huan, M. Laboratory measurements of small strain properties of dry sands by bender element. Soils Found. 2013, 53, 735-745. [CrossRef]

16. Clayton, C.R.I.; Khatrush, S.A.A. New device for measuring local axial strains on triaxial specimens. Géotechnique 1986, 36, 593-597. [CrossRef]

17. Castelblanco, J.M.; Delage, P.; Pereira, J.M.; Cui, Y.J. On-sample water content measurement for a complete local monitoring in triaxial testing of unsaturated soils. Géotechnique 2012, 62, 597-604. [CrossRef]

18. Jastrzębska, M.; Kowalska, M. Triaxial tests on weak cohesive soils-some practical remarks. Archit. Civ. Eng. Environ. 2016, 9, 91-103. [CrossRef]

19. Ye, G.L.; Wu, C.J.; Wang, J.F.; Wang, J.H. Influence and countermeasure of specimen misalignment to small-strain behavior of soft marine clay. Mar. Georesour. Geotechnol. 2017, 35, 170-175. [CrossRef]

20. Brown, S.F.; Snaith, M.S. The measurement of recoverable and irrecoverable deformations in the repeated load triaxial test. Géotechnique 1974, 24, 225-259. [CrossRef]

21. Cole, D.M. A Technique for measuring radial deformation during repeated load triaxial testing. Géotechnique 1978, 15, 426-429. [CrossRef] 
22. Khan, M.H.; Hoag, D.L.A. Noncontacting transducer for measurement of lateral strains. Can. Geotech. J. 1979, 16, 409-411. [CrossRef]

23. Brown, S.F.; Austin, G.; Overy, R.F. An instrumented triaxial cell for cyclic loading of clays. Geotech. Test. J. 1980, 3, 145-152. [CrossRef]

24. Burland, J.B.; Symes, M.A. Simple axial displacement gage for use in the triaxial apparatus. Géotechnique 1982, 32, 62-65. [CrossRef]

25. Costa-Filho, L.M. Measurement of axial strains in triaxial tests on London clay. Geotech. Test. J. 1985, 8, 3-13. [CrossRef]

26. Dupas, J.M.; Pecker, A.; Bozetto, P.; Fry, J.J. A 300 mm diameter triaxial cell with a double measuring device. Adv. Triaxial Test. Soil Rock 1988, 977, 142-1988.

27. Hird, C.C.; Yung, P.C.Y. Discussion on a new Device for measuring local axial strains on triaxial specimens. Géotechnique 1987, 37, 413-417. [CrossRef]

28. Hird, C.C.; Yung, P.C.Y. The use of proximity transducers for local strain measurements in triaxial tests. Geotech. Test. J. 1989, 12, 292-296.

29. Gunasekaran, M.; Robinson, R.G. On-sample measurement of strains in triaxial samples using strain gauges. Indian Geotech. J. 2008, 38, 33-48.

30. Hardin, B.O.; Drnevich, V.P. Shear modulus and damping in soils: Measurement and parameter effects. J. Soil Mech. Found. Div. 1972, 98, 603-624.

31. Hardin, B.O.; Drnevich, V.P. Shear modulus and damping in soils: Design equations and curves. J. Geotech. Eng. 1972, 98, 667-692.

32. Darendeli, B.M. Development of a New Family of Normalized Modulus Reduction and Material Damping Curves. Ph.D. Thesis, University of Texas, Austin, TX, USA, 2001.

33. Hurtado, J.; Newson, T. Small-strain behavior of a carbonate clay till underlying a wind turbine shallow foundation by different in-situ and laboratory tests. In Proceedings of the 69th Canadian Geotechnical Conference, Vancouver, BC, Canada, 2-5 October 2016.

34. Iwasaki, T.; Tatsuoka, F.; Takagi, Y. Shear moduli of sands under cyclic torsional shear loading. Soils Found. 1978, 18, 39-50. [CrossRef]

35. Michalowski, R.L.; Cermak, J. Triaxial compression of sand reinforced with fibers. J. Geotech. Geoenviron. Eng. 2003, 129, 125-136. [CrossRef]

36. Michalowski, R.L.; Zhao, A. Failure of fiber-reinforced granular soils. J. Geotech. Eng. 1996, 122, $226-234$. [CrossRef]

37. Acar, Y.; El-Tahir, A. Low strain dynamic properties of artificially cemented sand. J. Geotech. Eng. 1986, 112, 1001-1015. [CrossRef]

38. Saxena, S.K.; Avramidis, A.S.; Reddy, K.S. Dynamic moduli and damping ratios for cemented sands at low strains. Can. Geotech. J. 1988, 25, 353-368. [CrossRef]

39. Sharma, S.S.; Fahey, M. Deformation characteristic of two cemented calcareous soils. Can. Geotech. J. 2004, 41, 1139-1151. [CrossRef]

40. Trhlíková, J.; Boháč, J.; Mašín, D. Small-strain behavior of cemented soils. Géotechnique 2012, 62, $943-947$. [CrossRef]

41. Yun, T.S.; Santamarina, J.C. Decementation, softening, and collapse: Changes in small-strain shear stiffness in $\mathrm{k}_{0}$ loading. J. Geotech. Geoenviron. Eng. 2005, 131, 350-358. [CrossRef]

42. Mair, R.J. Developments in geotechnical engineering research: Application to tunnels and deep excavations. Proc. Inst. Civ. Eng. Civ. Eng. 1993, 93, 27-41.

43. Xu, D.; Borana, L.; Yin, J. Measurement of small strain behavior of a local soil by fiber Bragg grating-based local displacement transducers. Acta Geotech. 2014, 9, 935-943. [CrossRef]

44. Fahey, M.; Carter, J.P. A finite element study of the pressuremeter test in sand using a nonlinear elastic plastic model. Can. Geotech. J. 1993, 30, 348-362. [CrossRef]

45. Oztoprak, S.; Bolton, M.D. Stiffness of sand through a laboratory test database. Géotechnique 2013, 63, 54-70. [CrossRef]

46. Schmidt, C.J.R. Static and Dynamic Response of Silty Toyoura Sand with PVA Fiber and Cement Additives. Master's Thesis, Western University, London, ON, Canada, 2015. 
47. Nakamichi, M.; Sato, K. A method of suppressing liquefaction using a solidification material and tension stiffeners. In Proceedings of the International Conference on Soil Mechanics and Geotechnical Engineering, Paris, France, 2-6 September 2013.

48. Safdar, M. Monotonic Stress-Strain Behavior of Fiber Reinforced Cemented Toyoura Sand. Ph.D. Thesis, Western University, London, ON, Canada, 2018.

49. Lam, W.K.; Tatsuoka, F. Effects of initial anisotropic fabric and sigma2 on strength and deformation characteristics of sand. Soils Found. 1988, 28, 89-106. [CrossRef]

50. De, S.; Basudhar, P.K. Steady state strength behavior of Yamuna sand. Geotech. Geol. Eng. 2008, 26, $237-250$.

51. ASTM D854-10. Standard Test Methods for Specific Gravity of Soil Solids by Water Pycnometer; ASTM International: West Conshohocken, PA, USA, 2012.

52. Yamaguchi, H.; Kimura, T.; Fuji-I, N. On the influence of progressive failure on the bearing capacity of shallow foundations in dense sand. Soils Found. 1976, 16, 11-22. [CrossRef]

53. Whitlow, R. Basic Soil Mechanics, 4th ed.; Prentice Hall: Upper Saddle River, NJ, USA, 2001.

54. ASTM C150/C150M-12. Standard Specification for Portland Cement; ASTM International: West Conshohocken, PA, USA, 2012. [CrossRef]

55. Ladd, R.S. Preparing test specimens using undercompaction. Geotech. Test. J. 1978, 1, 16-23.

56. ASTM D7181-11. Method for Consolidated Drained Triaxial Compression Test for Soils; ASTM International: West Conshohocken, PA, USA, 2011.

57. Shafiq, N.; Nuruddin, M.F. Degree of hydration of OPC and OPC/fly ash paste samples conditioned at different relative humidity. Int. J. Sustain. Constr. Eng. Technol. 2010, 1, 47-56.

58. Kiss, J.A. Evaluation of Fatigue Response of a Carbonate Clay Till Beneath Wind Turbine Foundation. Master's Thesis, Western University, London, ON, Canada, 2016.

59. Head, K.H. Manual of Laboratory Testing: Effective Stress Tests; ELE International Limited: New York, NY, USA, 1986; Volume 3.

60. Gray, D.H.; Al-Refeai, T. Behavior of fabric-versus fiber-reinforced sand. J. Geotech. Eng. 1986, 112, 804-820. [CrossRef]

61. Diambra, A. Fiber Reinforced Sands: Experiments and Modelling. Ph.D. Thesis, University of Bristol, Bristol, UK, 2010.

62. Din, S.U. Behavior of Fiber Reinforced Cemented Sand at High Pressures. Ph.D. Thesis, University of Nottingham, Nottingham, UK, 2012.

63. Claria, J.J.; Vettorelo, P.V. Mechanical behavior of loose sand reinforced with synthetic fibers. Soil Mech. Found. Eng. 2016, 53, 11-15. [CrossRef]

64. Consoli, N.C.; Vendruscolo, M.A.; Fonini, A.; Rosa, F.D. Fiber reinforcement effects on sand considering a wide cementation range. Geotext. Geomembr. 2009, 27, 196-203. [CrossRef]

65. Schnaid, F.; Prietto, P.; Consoli, N. Characterization of cemented sand in triaxial compression. J. Geotech. Geoenviron. Eng. 2001, 127, 857-868. [CrossRef]

66. Porcino, D.; Marcianò, V.; Granata, R. Static and dynamic properties of a lightly cemented silicate-grouted sand. Can. Geotech. J. 2012, 49, 1117-1133. [CrossRef]

67. Sadek, S.; Najjar, S.; Abboud, A. Compressive strength of fiber-reinforced lightly-cement stabilized sand. In Proceedings of the 18th International Conference on Soil Mechanics and Geotechnical Engineering, Paris, France, 2-6 September 2013.

68. Toutanji, H.A.; Xu, B.; Lavin, T.; Gilbert, J.A. Properties of polyvinyl alcohol fiber reinforced high performance organic aggregate cementitious material. In Proceedings of the International Congress on Polymers in Concrete, Funcal, Madeira Island, Portugal, 10-12 February 2010; pp. 1-10.

69. Al-Attar, T.S. A quantitative evaluation of bond strength between coarse aggregate and cement mortar in concrete. Eur. Sci. J. 2013, 9, 22-35.

Publisher's Note: MDPI stays neutral with regard to jurisdictional claims in published maps and institutional affiliations. 